\title{
Multidetector Computed Tomographic Urography For Evaluation Of Crossed Fused Renal Ectopia
}

\author{
Çapraz Füzyone Renal Ektopinin Değerlendirilmesinde Multidedektör Bilgisayarlı Tomografik Ürografi
}

Aysel Türkvatan, Tülay Ölçer, Turhan Cumhur, Pınar Özdemir Akdur

Türkiye Yüksek Ihtisas Hastanesi, Radyodiagnostik Anabilim Dalı

Received: 12.11.2007 • Accepted: 17.02.2008

Corresponding author

Uzm. Dr. Aysel Türkvatan

Türkiye Yüksek Ihtisas Hastanesi, Radyodiagnostik Anabilim Dalı

Phone :+90(312) 3061000

E-mail address : aturkvatan@yahoo.com

Crossed fused renal ectopia is generally an incidental finding for an otherwise normal kidney, but associated with various urological abnormalities. To date, the diagnosis of this abnormality was made by ultrasonography, excretory urography and computed tomography. Multidetector computed tomographic (MDCT) urography depicts the normal urinary tract anatomy, including both the renal parenchyma, collecting structures and ureters. Congenital fusion anomalies of kidney are easily depicted with MDCT urography than with conventional computed tomography. Herein we report four cases of crossed fused renal ectopia associated with other urological abnormalities that was suspected or diagnosed by ultrasonography and confirmed by MDCT urography and review the available literature. This report underlines the importance of MDCT urography in the diagnosis of congenital anomalies of urinary tract especially renal fusions.

Key Words: crossed fused renal ectopia, renal fusion, ectopic kidney, congenital renal malformation, MDCT

Çapraz füzyone renal ektopi, genellikle diğer yönlerden normal olan bir böbrekte rastlantısal bir bulgudur ancak çeşitli ürolojik anomalilerle birliktelik gösterebilir. Bu anomalinin tanısı, günümüze kadar ultrasonografi, eksretuar ürografi ve bilgisayarlı tomografi ile yapılmıştır. Multidetektör bilgisayarlı tomografik (MDBT) ürografi, normal üriner trakt anatomisini hem renal parankimi hem de toplayıcı sistem ve üreterleri içerecek şekilde gösterir. Böbreğin konjenital füzyon anomalileri, MDBT ürografi ile konvansiyonel bilgisayarlı tomografiye oranla daha kolay olarak gösterilir. Biz burada diğer ürolojik anormallikler ile birliktelik gösteren, ultrasonografide şüphelenilen ya da tanı alan ve tanısı MDBT ürografi ile teyid edilen çapraz füzyone renal ektopili dört olguyu sunduk ve mevcut literatürü gözden geçirdik. Bu rapor, özellikle renal füzyonlar başta olmak üzere üriner traktın konjenital anomalilerinin tanısında MDBT ürografinin önemini vurgulamaktadır.

Anahtar Kelimeler: çapraz füzyone renal ektopi, renal füzyon, ektopik böbrek, konjenital renal malformasyon, MDBT

Crossed fused renal ectopia is an uncommon congenital anomaly in which one kidney crosses over to opposite side and parenchyma of the two kidneys fuse. Most commonly, the upper pole of the inferiorly positioned crossed ectopic kidney is fused to the lower pole of the superior, normally positioned kidney. The ureter of the ectopic kidney crosses the midline and enters the bladder on the opposite side (1). The condition itself is generally not associated with symptoms, unless it is complicated by obstruction or infection, and diagnosed an incidental finding.
However, when diagnosed, further investigation is warranted to exclude other correctable pathology in the urinary tract. We report four cases of crossed fused renal ectopia associated with urological abnormalities, that was suspected or diagnosed by ultrasonography and confirmed by multidetector computed tomographic (MDCT) urography and review the available literature. Our paper underlines the importance of MDCT urography in the diagnosis of congenital anomalies of urinary tract especially renal fusions. 


\section{Case Reports}

Four patients (2 female, 2 male), ranging in age from 23 years to 69 years, were examined for a variety of reasons. All patients were sonographically suspected or diagnosed as having crossed fused renal ectopia. The diagnosis was confirmed in all patients by MDCT urography. MDCT urography was performed with a 16-row multislice CT (Light-speed Ultra, GE medical System, Wisc., USA) and the following protocol was implented; scans are obtained in three phases: unenhanced, nephrographic phase and pyelographic phase. Additionally, in the case 3 and 4 delayed pyelographic phase images were obtained. Patient is positioned supine and receive a supplemental infusion of $250 \mathrm{ml}$ normal saline immediately following the injection of contrast medium. Initial unenhanced images are obtained from the diaphragm to the symphysis pubis with 2.5 $\mathrm{mm}$ collimation and $1.25 \mathrm{~mm}$ reconstruction interval. A nephro- graphic phase acquired with 2.5 $\mathrm{mm}$ collimation $100 \mathrm{sec}$ after administration of $100 \mathrm{cc}$ of iodinated contrast agent (lodixanol, Visipaque $320 \mathrm{mgl} / \mathrm{ml}$, GE Healthcare Bio-Sciences, USA) a rate of $3 \mathrm{ml} /$ sec and a pyelographic phase acquired after a 10 min delay with $1.25 \mathrm{~mm}$ collimation. For 3-dimensional image reconstruction, the raw $\mathrm{CT}$ data were processed on a separate workstation (Advanced Workstation 4.2, GE Medical System, Wisc., USA) with multiplanar reformatting, maximum intensity projection and volume rendering.

\section{Case 1}

A 51-year-old woman with history of multiple urinary tract infections, presented with a left lumbar pain. Urinalysis showed pyuria. The sonogram demonstrated the absence of a right kidney, and the presence of two kidneys in the left renal fossa joined by a parenchymal tissue. A mild degree of hydronephrosis and a stone $20 \mathrm{~mm}$ in diameter in the lower pole of the left superior kidney were detected. A MDCT urography confirmed the ultrasound findings and revealed the fusion of of the lower pole of the normally located left kidney and the upper pole of the right ectopically located kidney. Axial images showed contrast enhancement of thickened wall of the renal pelvis and stranding of the fat in the vicinity of the inflamed renal pelvis in the left superior kidney. The attenuation value of the infected fluid was $25 \mathrm{HU}$. The diagnosis of crossed fused renal ectopia with pyonephrosis was made (Figure 1).

\section{Case 2}

A 40-year-old male presented with hypertension. Blood pressure was $90 / 140 \mathrm{mmHg}$. Labaratory studies revealed mild hypercholesterolemia. The sonogram demonstrated the absence of left kidney, and the presence of two kidneys in the right renal fossa, indistinguishable from one another. Renal Doppler ultrasound showed normal

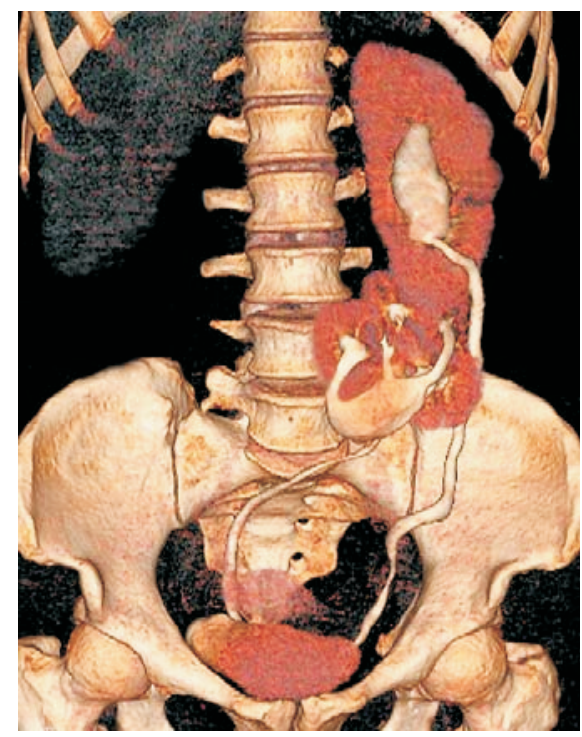

Figure 1 (A)

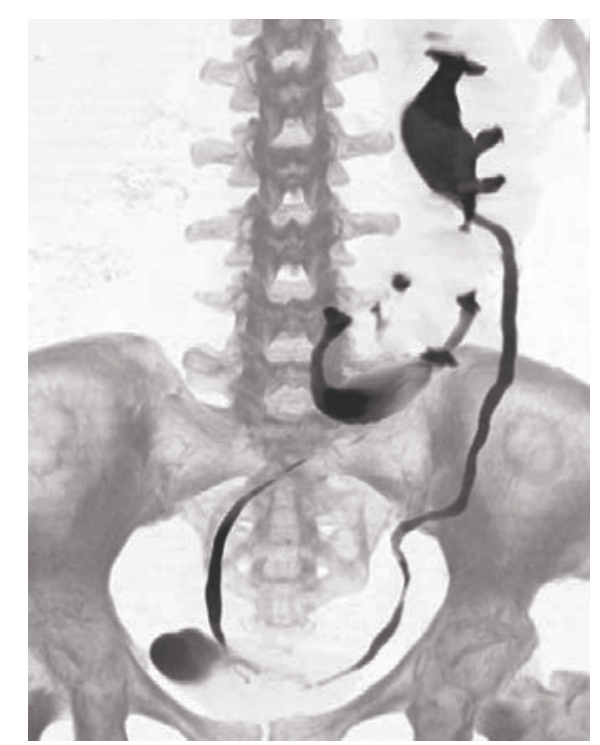

Figure $1(B)$

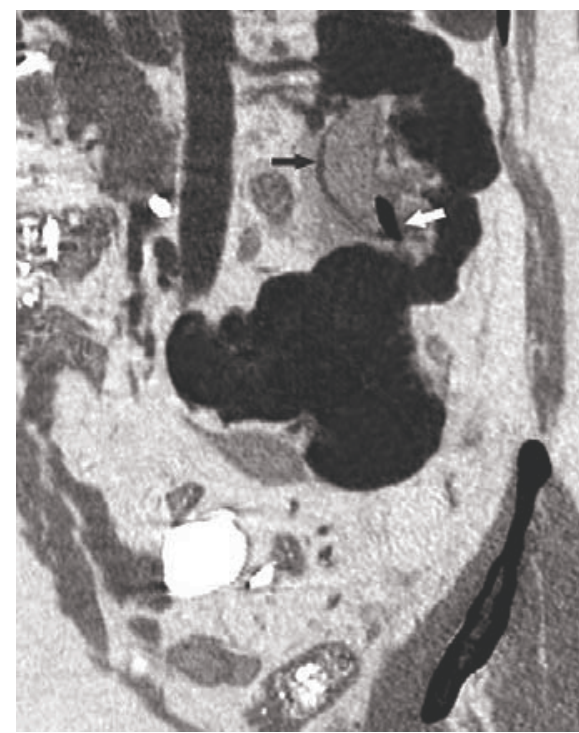

Figure 1 (C)

Figure 1. Coronal volume rendering (A) and maximum intensity projection (B) images show crossed fused renal ectopia on the left side. The ureter of the right ectopic kidney crosses the midline and enters the bladder on the opposite side. Oblique multiplanar reforma tting image in the nephrographic phase (C) shows a mild degree of hydronephrosis, contrast enhancement of thickened wall of the renal pelvis (white arrow) and a stone (black arrow) in the lower pole of the left superior kidney. In addition, stranding of the fat in the vicinity of the i nflamed renal pelvis in the left superior kidney is also seen. 


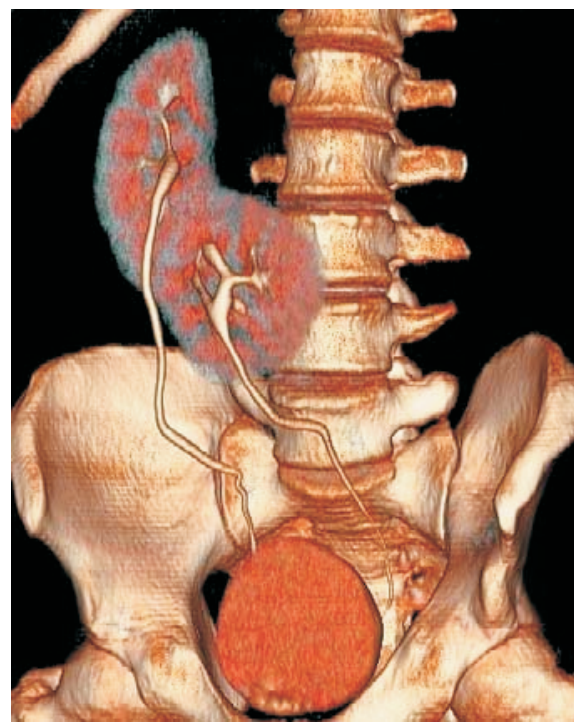

Figure 2 (A)

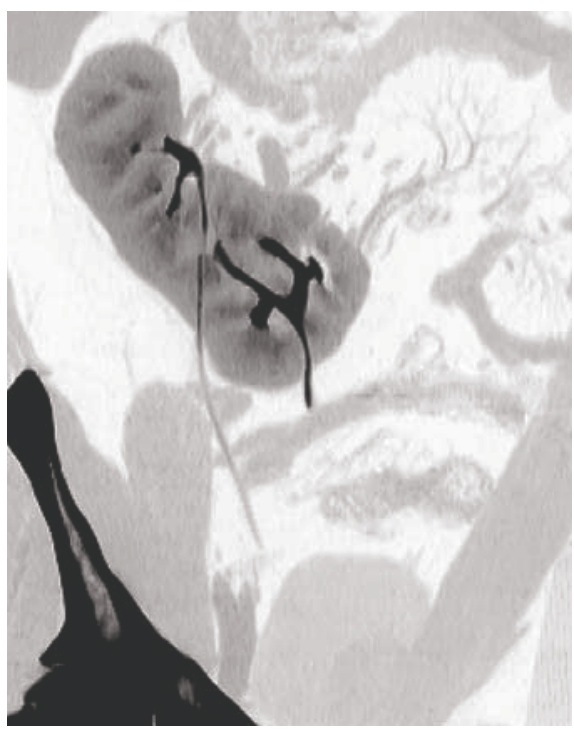

Figure 2 (B)

Figure 2. Coronal volume rendering $(\mathbf{A})$ and maximum intensity projection $(\mathbf{B})$ images show crossed fused renal ectopia on the right side. The ureter of the left ectopic kidney crosses the midline and enters the bladder on the opposite side.

renal artery in the right superior kidney, but did not demonstrate the renal artery of the left ectopic kidney clearly due to bowel gas superposition. Renal MDCT angiography revealed the renal artery of right superior kidney arose from the aorta at the normal location and it had prehilar branching. Two renal arteries were present at the

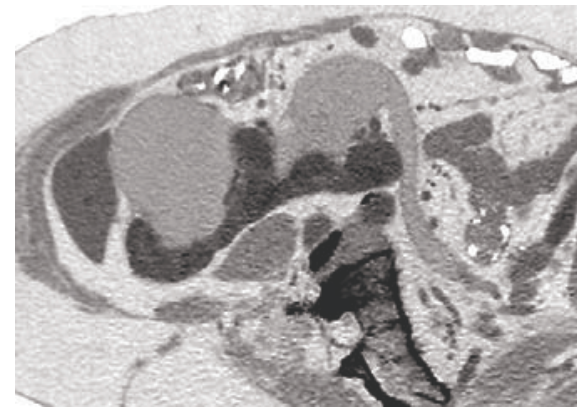

left ectopic inferior kidney. One of them arose from distal abdominal aorta, with prehilar branching, and other arose from left common iliac artery. In all of the renal arteries was not detected stenoses. The pyelographic phase images, acquired after a 10 min delay, confirmed diagnosis of crossed fused renal ectopia (Figure 2).

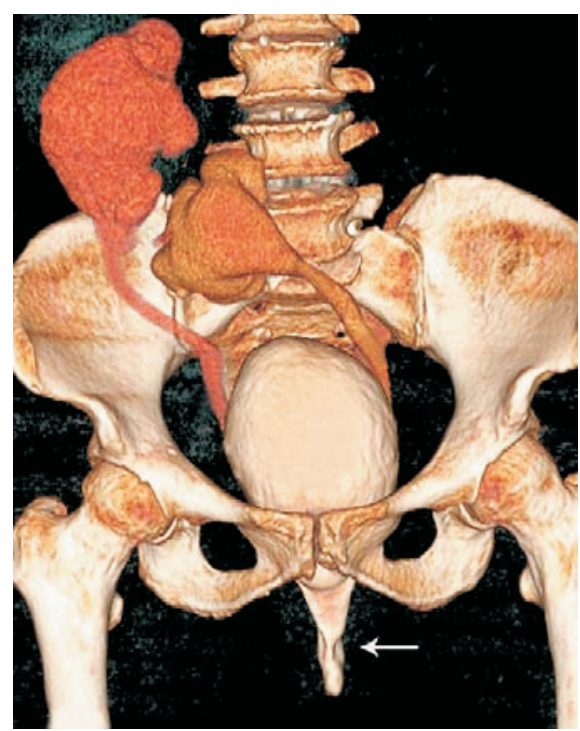

Figure 3 (B)

\section{Case 3}

A 69-year-old woman with considered for surgical intervention for pelvic organ prolapsus presented with bilateral lumbar pain. An ultrasound showed two kidneys were located in the right renal fossa which could not be separated. Severe hydronephrosis was present in both kidneys. MDCT urography revealed crossed fused renal ectopia with severe hydronephrosis. No stone was detected both either in collecting systems or ureters. Prolapse of bladder and uterus was detected. The delayed pyelographic phase images clearly demonstrated that both ureters were entrapped by the genital hiatus and obstructed. Crossed fused renal ectopia with severe hydronephrosis secondary to pelvic organ prolapsus was diagnosed (Figure 3). Ultrasonography 3 months after operation showed no hydronephrosis in the both kidney.

Figure 3 (A)

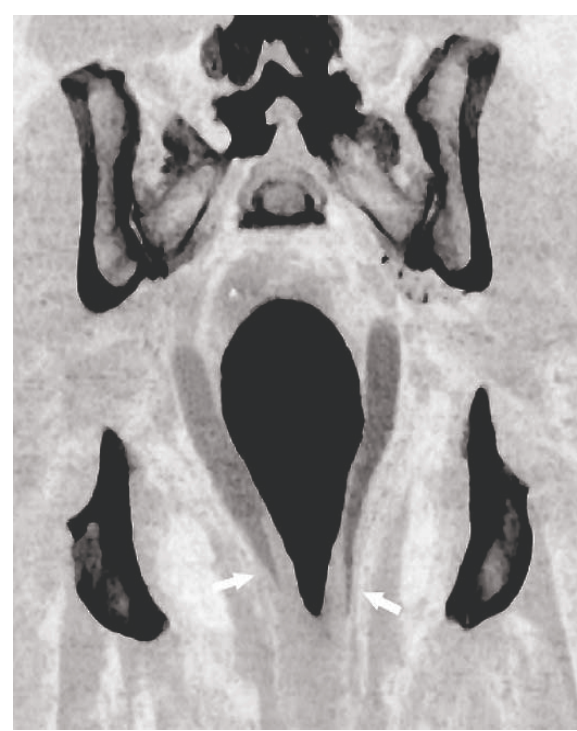

Figure 3 (C)

Figure 3. Oblique multiplanar reformatting image in the nephrographic phase (A) and coronal volume rendering image in the delayed pyelographic phase (B) show crossed fused renal ectopia with severe hydronephrosis. Bladder prolapsus is also seen (arrow). Coronal maximum intensity projection image (C) demonstrate that both ureters entrapped by the genital hiatus and obstructed (arrows). 


\section{Case 4}

A 23-year-old male presented with a left lumbar pain. The sonogram demonstrated the right kidney was located in the midline and fused to the inferior pole of the left kidney with advanced hydronephrosis. A MDCT urography revealed the right kidney, in a transverse position, it was located in the midline anterior to the fourth and fifth lomber vertebra and fused the lower pole of the left normally located kidney. Advanced hydronephrosis of the left kidney was detected. No stone was detected in the left collecting system and ureter. In the pyelographic phase images, were acquired after a 10 min delay, was not seen a pyelogram in the left kidney. The delayed pyelographic phase images after 45 min delay showed a pyelogram in the left kidney. L-shaped crossed fused renal ectopia and advanced hydronephrosis of the left kidney secondary to pelvicureteric junction obstruction was diagnosed (Figure 4).

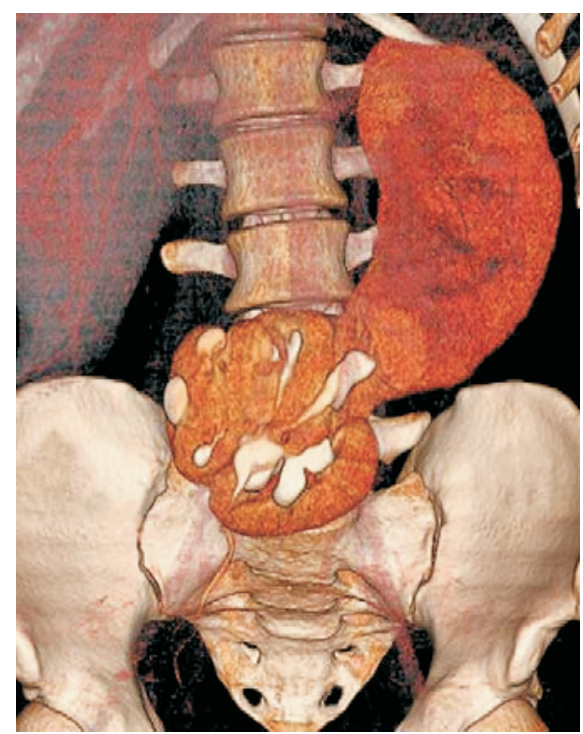

Figure 4 (A)

\section{Discussion}

Renal fusion anomalies are cake kidney (complete renal fusion), crossed fused renal ectopia and horseshoe kidney. Cake kidney is an anomaly characterized by complete fusion of both kidneys and accounts for only $2 \%$ of these fused kidneys (2). A partial renal fusion is represented by the horseshoe kidney and crossed renal ectopia with fusion. The commonest type of fusion anomaly is the horseshoe kidney which results when the axes of the kidneys are altered by a medial shift of the lower poles (or, rarely the upper poles) which are joined by a preaortic isthmus of renal parenchyma or fibrous tissue in the midline. It accounts for $90 \%$ of all renal fusion anomalies and occurs with incidence of about $0.25 \%$ of the population $(1,2)$.

Crossed fused renal ectopia is the second most common fusion abnormality of the kidney, with an estimated incidence of approximately 1:1300-1:7500 (3). In crossed

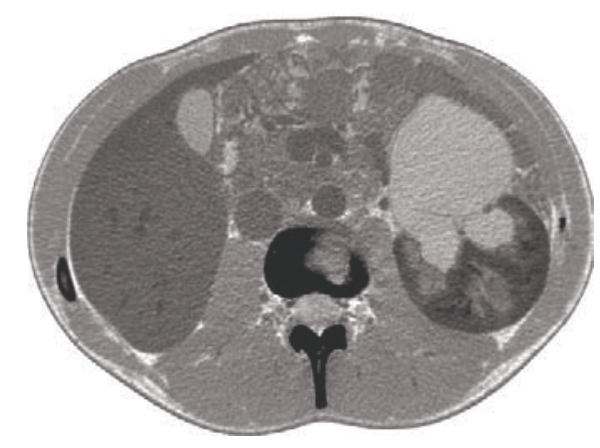

Figure 4 (B) fused ectopia, the kidneys both lie in one side of the abdomen and one ureter will cross the midline. The left kidney is most frequently ectopic (crossing to the right side of the abdomen) and there is a slightly higher incidence in males (1). Most cases are sporadic but dominant inheritance has been reported (3).

Mcdonald and Mc Clellan classified crossed ectopic kidney into four types; crossed renal ectopia with fusion $(85 \%)$, crossed renal ectopia without fusion $(10 \%)$, solitary crossed renal ectopia and bilaterally crossed renal ectopia (4). Six variations of crossed fusion have been described. In decreasing order of frequency, they are; type 1: inferior crossed fused ectopia, type 2: sigmoid or S-shaped kidney, type 3: unilateral lump kidney, type 4: unilateral disc kidney, type 5: L-shaped kidney, type 6: superior crossed fused ectopia (1).

The etiology of crossed fused renal ectopia has been assumed to be due to a number of possible fac-

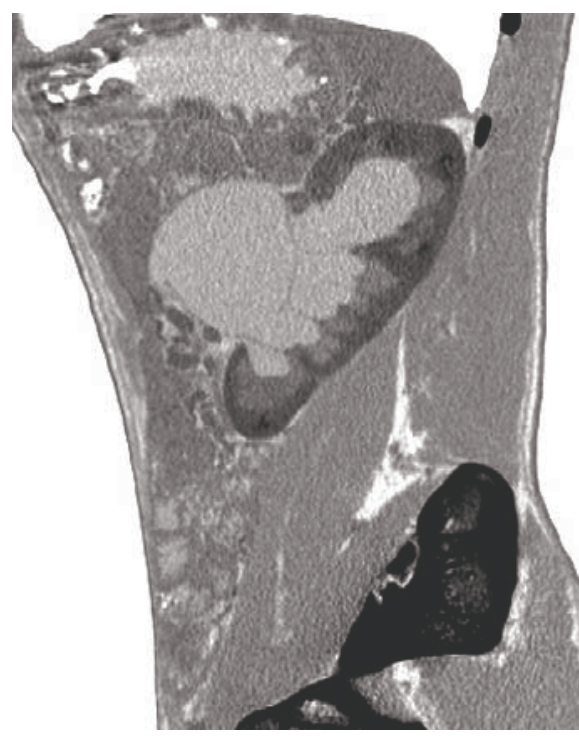

Figure 4 (C)

Figure 4. Coronal volume rendering image in the pyelographic phase (A) shows crossed fused renal ectopia on the left side. The pyelogram of the left superior kidney was not seen. Axiel (B) and sagittal multiplanar reformatting image in the pyelographic phase (C) show severe hydronephrosis in the left superior kidney. 
tors, including; teratogens, aberrant development of the caudal end of the fetus with abnormal rotation, a wandering ureteral bud inducing differentiation of the kidney on the opposite side, and pressure from abnormally located umbilical arteries preventing cephaled migration of the renal unit prompting migration to the opposite side along the path of least resistance. Fusion can occur at any time during the migration or ascent of the crossed kidney (1).

In all of fused kidneys, the arterial supply and venous drainage are grossly abnormal. This reflects the primitive arrangement variably seen in ectopic kidneys, often because of their very limited rostral migration. Blood supply to the ectopic kidney most frequently arises from the vessels on the ipsilateral side, but occasionally from the contralateral side. Both the normally located kidney and its fused mate commonly have abberant arterial anatomy, with arterial supply from the upper abdominal aorta in $25 \%$ of cases, and the remainder from the lower aorta or iliac arteries. While the total number of arteries ranges from one to six, most commonly there are two to four major arteries to the two kidneys $(1,5)$.

Generally, cross fused renal ectopia is typically asymptomatic and is diagnosed as an incidental finding when the patient is examined for other medical diseases. When symptoms do occur, the most common symptoms reported are: abdominal or flank pain, a palpable mass, hematuria, dysuria and urinary tract infections. The urological conditions associated with this anomaly are: nephrolithiasis, ureteropelvic junction obstruction, hydronephrosis, reflux, multicystic displasia, ectopic ureterocele (1). The abnormal position of the kidney can lead to poor outflow and a predisposition to hydonephrosis, calculi, and infection $(1,5)$. Tumors in crossed ectopic kidneys have been reported sporadically (6).

Pediatric patients most often present with multiple congenital anomalies, especially of the skeletal anomalies of the bony pelvis and vertebra. Other anomalies associated with this condition are cardiovascular, gastrointestinal and other genitourinary anomalies, as previously mentioned (1).

Hypertension has been diagnosed in patients with crossed renal ectopia. However a causal link is not usually established (1). In one case report of an infant with renal arterial stenosis secondary to crossed renal ectopia, renovascular hypertension was present (7). In our case 2 with hypertension was not detected stenoses all of the renal arteries.

Hydronephrosis may be associated with pelvic organ prolapsus as in our case 3 . Several theories have been proposed to explain the association of hydronephrosis with pelvic organ prolapsus. The most recent and widely accepted explanation is that the ureters become entrapped by the genital hiatus against the fundus of the uterus (8). In our case 3, MDCT urography clearly demonstrated that both ureters were entrapped by the genital hiatus and obstructed.

To date, the diagnosis of crossed fused renal ectopia was made by ultrasonography, excretory urography and computed tomography (CT). Ultrasound is often the initial procedure performed in the workup of the patient. The sonographic appearance of this anomaly consist of a characteristic anterior and/or posterior notch, difference in orientation of the two collecting systems in the fused kidneys, and absence of a kidney in the contralateral renal fossa, or elsewhere in the abdomen or pelvis (9). Excretory urography is often useful, but the absence of fusion may not be apparent unless the two renal masses are widely separated. CT allow accurate diagnosis. The advantage of MDCT urography is its ability to depict the normal urinary tract anatomy, including both the renal parenchyma and collecting structures and ureters. Congenital anomalies of the collecting system and ureters can be visualized better with MDCT urography than with conventional CT. Congenital anomalies of renal position, number and form are easily depicted with MDCT urography, including renal ectopia, malrotation and fusion anomalies (10).

The differential diagnosis includes a solitary kidney with compensatory hyperplasia, a solitary kidney containing a mass, a solitary kidney containing a double collecting system, a horseshoe kidney, and massive displacement of the kidney by an abdominal mass (9).

Crossed fused renal ectopia is usually diagnosed as an incidentally, when patient is examined for other reasons, unless it is complicated by obstruction or infection. Yet, when it is diagnosed, further investigation is necessary to rule out other correctable pathologies in the urinary tract and concurrent congenital anomalies. MDCT urography in which both axial and 3-dimensional images are evaluated are useful for revealing urinary tract anatomy and pathologic conditions and it is promising as an alternative to excretory urography. Especially coronally reformatted MDCT urograms can provide good delineation of congenital anomalies of urinary tract especially renal fusions. 


\section{REFERENCES}

1. Bauer SB. Anomalies of the upper urinary tract. In: Walsh PC, Retik $A B$, Vaughan ED, Wein AJ, editors. Campbell's Urology. 8th ed. Philadelphia: W.B.Saunders Co.; 2002. p 1898-1906.

2. Kaufmann MH, Findlater GS. An unusual case of comlete renal fusion. Giving rise to a 'cake' or 'lump' kidney. J Anat 2001; 198:501-4.

3. Rinat Choni, Farkas Amicur, Frishberg Y. Familial inheritance of crossed fused renal ectopia. Pediatr Nephrol 2001; 16: 269-70.
4. McDonald JH, McClellan DS. Crossed renal ectopia. Am J Surg. 1957; 93: 995-99.

5. Bailey SH, Mone MC, Nelson EW. Transplantation of crossed fused ectopic kidneys into a single recipient. J Am Coll Surg 2002; 194: 147-50.

6. Gerber WL, Culp DA, Brown RC, Chow KC, Platz CE. Renal mass in crossed- 10. fused ectopia. J Urol 1980; 123: 23944.

7. Mininberg DT, Roze S, Yoon HJ, Pearl M. Hypertension associated with crossed renal ectopia in an infant. Pediatrics 1971; 48: 455-57.
8. Hadar H, Meiraz D. Total uterine prolapse causing hydroureteronephrosis. Surg Gynecol Obstet 1980; 150:711-4.

9. Goodman JD, Norton KI, Carr L, Yeh HC. Crossed fused renal ectopia: sonographic diagnosis. Urol Radiol 1986; 8: 13-6.

10. Chow LC, Sommer FG. Multidetector CT urography with abdominal compression and three-dimensional reconstruction. Am J Roentgenol 2001; 177: 849-855. 